\title{
Nutrient reserves in Southland soils
}

\author{
C.C. BOSWELL ${ }^{1}$, W.H. RISK ${ }^{2}$, R.P. LITTLEJOHN ${ }^{1}$, B. SWANNEY ${ }^{1}$, G.M. GRAY ${ }^{2}$, and L.C. SMITH ${ }^{2}$ \\ ${ }^{1}$ AgResearch Invermay Agricultural Centre, Private Bag, Mosgiel \\ ${ }^{2}$ AgResearch Woodlands Research Station, Private Bag, Invercargill
}

\begin{abstract}
The major plant nutrients in soils were measured from 53 Southland sites arranged along 4 transects which extended inland from the southem coast and one which extended westwards from Papatowai on the east coast to Manapouri in the west. Soil samples were taken from 8 depths: O-75.75-150, $150-225,225-300,300-450,450-600,600-750$, and $750-900 \mathrm{~mm}$, at each site. In zonal soils, sulphate accumulated deeper in the soil profile and declined logarithmically with distance from the southern coast. In recent soils there was little accumulation in the profile. Rainfall sulphur is the most likely source of the reserves. Magnesium accumulated deep in the profile of inland soils in western transects, suggesting that serpentine rock parent material was its source. Generally, available phosphorus, calcium, potassium, total nitrogen and organic carbon concentrations were greatest in the surface layer of soil and declined with soil depth. However, very high phosphate reserves were present deep in the profile at a few specific inland sites. Short-term sustainable agricultural systems could involve the utilisation of at least some of these reserves. This would require the encouragement of deeper-rooting of plants than currently occurs under pastoral systems.
\end{abstract}

Keywords magnesium, nutrient reserves, phosphorus, Southland, sulphate, sustainable agriculture, transects

\section{Introduction}

Sustainable agricultural systems imply continued production over long periods of time without depleting natural resources such as the reserves of nutrients in soils. Alternative sustainable systems may differ radically from existing production systems because they may involve better utilisation of nutrient reserves, and, where reserves are large, may involve short-term mining of them. However, in soils with limited reserves mining of them is not consistent with sustainability. A major challenge in modem agriculture is to use soil nutrient reserves in sustainable agricultural production systems; essentially this involves tapping into reserves and recycling them effectively. The first requirement is to know what the nutrient reserve status of soils is before any sustainable system is planned. The concentration of nutrients in the surface $75 \mathrm{~mm}$ of soil is taken as a convenient index of the immediate nutrient status. Long-term reserves can be assessed only by examining the whole soil profile.

An earlier report of large reserves of subsoil sulphate from a few Southland sites on yellow-brownearth soils suggested a relationship between sulphate reserves and rainfall (Risk \& Boswell1988). A survey of sulphur input in rainfall across Southland was conducted at the same sites as are reported in this paper. It showed that inputs of sulphur in rain were strongly associated with the logarithm of distance from the south coast (Boswell et al. 1993). Soil sulphate reserves were therefore similarly analysed in association with distance from the south coast.

A broad account of the levels of most other available nutrients distributed in the A and B horizons of soils throughout New Zealand is available from singlefactor maps (New Zealand Soil Bureau 1962). However, the maps havelirnitations for planning sustainable systems because they usually involve the upper horizons of the soil profile and the nutrient levels are a mean range of values representative of relatively broad soil group mapping units.

\section{Methods}

The locations of the soil sites along five transects are shown in Figure 1. Sites were on developed pastures whichgenerallyreceivedregularfertiliserapplications.

In Transect 3 soil samples were taken from both older terraces (zonal soils $=3 \mathrm{a}$ ) and from adjacent recent soils (recent soils $=3 \mathrm{~b})$. Ten to 15 cores $($ diameter $25 \mathrm{~mm}$ ) were taken to the following depths at each site : O-75, $75-150,150-225,225-300,300-450,450-600,600-750$, $750-900 \mathrm{~mm}$. Samples were dried overnight at $35^{\circ} \mathrm{C}$, ground to pass a $2 \mathrm{~mm}$ sieve, and analysed by standard MAF quick test analysis (Blackmore et al. 1972; Sinclair\& Enright 1982). Analyses includedexchangeable cations calcium $(\mathrm{Ca})$, magnesium $(\mathrm{Mg})$, potassium $(\mathrm{K})$, sodium (Na), extracted in $1 \mathrm{~N}$ ammonium acetate; sulphate sulphur (S) extracted by calcium dihydrogen 


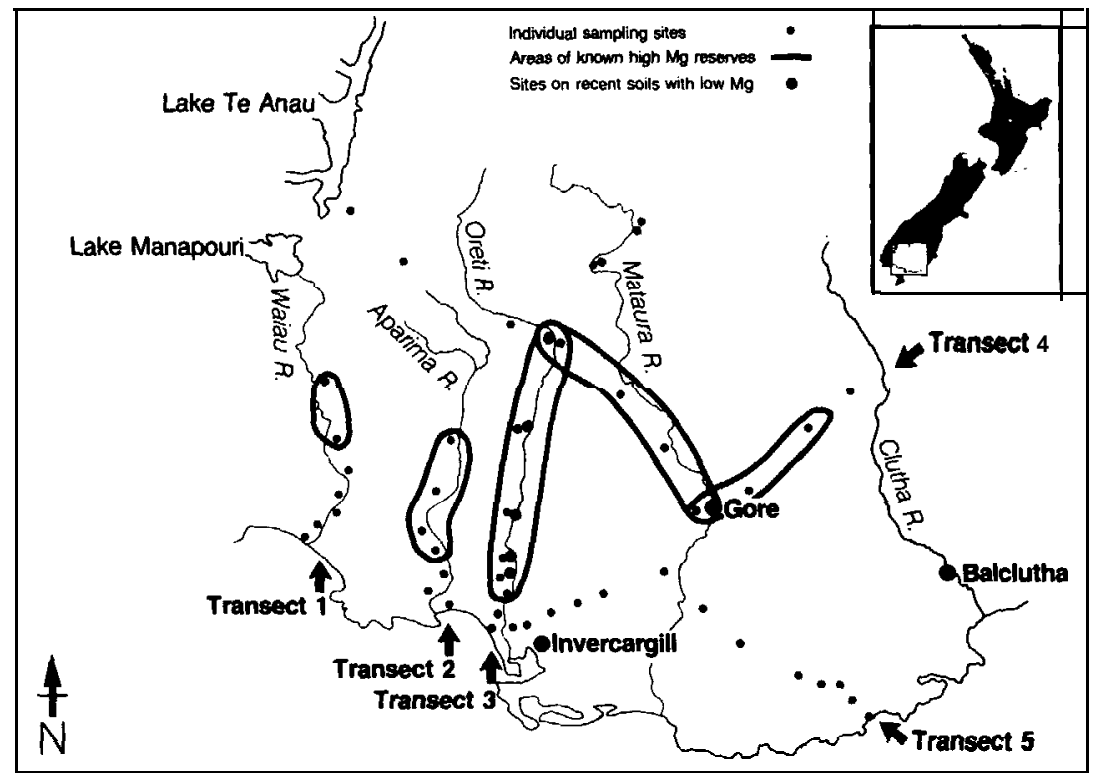

Flqure 1 Map of Southland showing location of soil sampling sites, and zones of bigh soil exchangeable magnesium reserves.

phosphate at $\mathrm{pH} 4.0$; available phosphorus (P) $\mathbf{1} / 2$ hour

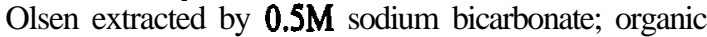
carbon $(\mathrm{C})$ and total nitrogen $(\mathrm{N})$.

The dependence of sulphate concentration on soil depth and distance from the coast for each transect was investigated by multiple regression, fitting the equation

$\log \left(\mathbf{S O}_{4}\right)=\mathrm{a}+\mathrm{b} \times$ depth $+\mathrm{c} \times \log ($ dist $)+\mathrm{d} \times$ depth $\mathrm{x} \log$ (dist)....equation 1

where dist is the distance from the south coast.

The logarithms of sulphate concentration and distance are taken to linearise the relationship. A high value of $b$ indicates that close to the coast sulphate concentration increases rapidly down the soil profile, while a large negative value of $\mathrm{c}$ indicates that the surface concentration of sulphatedecreases rapidly with distance from the south coast. The interaction between soil depth and distance from the coast is incorporated into the model by the parameter $d ; a$ large negative value of $d$ indicates that sulphate concentrations at depth decrease along the transect more rapidly than in surface soils. If they were not significant, the parameters $\mathrm{d}$ followed by band/or $\mathrm{c}$. were dropped from the model. In each transect the coastal site, which in most cases was a sand occupying an unrepresentative narrow coastal strip, was not included in the regression analysis.

\section{Results and discussion}

Quantitatively the greatest reserves were of sulphate followed by magnesium and, in isolated locations, phosphorus. Highest reserves occurred where the nutrients accumulated at depth in the soil profile. With the other nutrients and usually with phosphorus, reserves were limited and were greater in the surface layers of the soil than at depth.

Subsoil sulphate reserves varied between transects, and between recent soils and zonal soils on Transect 3 . The parameter estimates for fitting Equation 1 to the sulphate data are given in Table 1. For Transect 1 there was little variation in sulphate concentration with depth or distance from the coast. In Transects $\mathbf{2 , 3 a}, 4$ and 5 , parameters indicate large sulphate reserves below 450 $\mathrm{mm}$ near the coast, decreasing to modest levels by 100 $\mathrm{km}$ inland. In Transect $3 \mathrm{~b}$ on recent soils, sulphate concentration did not vary substantially with depth, but it declined in the more inland sites relative to those nearer the coast. Figure 2 summarises the differences between mean soil sulphate concentrations in the 450 $900 \mathrm{~mm}$ depth in recent soil and zonal soils (Transects $3 b$ and $3 a$ respectively). Where sulphate concentrations were greatest the total profile reserves of sulphate-S are estimated to be $930 \mathbf{~ k g} / \mathbf{h a}$. The accumulationof reserves below $450 \mathrm{~mm}$ is beneath the normal rooting depth of summermoist temperate pasture plants (Risk \& Boswell 1988).

Regression analyses of mean soil sulphate at 450 $900 \mathrm{~mm}$ depth on annual $\mathrm{S}$ input per hectare in rainfall (Boswell et al. 1993) were significant on all transects (Figure 3). This indicates that long term accumulation of rainfall sulphate is a moreimportant source of the subsoil sulphate reserves than fertiliser sulphate inputs over the last 100 years.

Areas with high subsoil reserves of $\mathrm{Mg}$ in this survey are shown in Figure 1. In contrast to sulphate, the 
major contributor to soil $\mathbf{M g}$ is the parent material. Magnesium reserves at $\mathbf{4 5 0 - 9 0 0 ~} \mathrm{mm}$ were highest at Lumsden (Figure 1), near the serpentine rocks at the end of the Red Mountain ultrabasic rocks. Reserves declined from 64 ppm sathwerch down the Oreti River (Transect 3) at a rate of about $\mathrm{D} \mathbf{p p m} / \mathbf{k m}$, andsouth-eastwards to Gore along the Mataura River system at a rate of about $4 \mathrm{ppm} / \mathrm{km}$. In addition there are small areas with mod-

Table 1 Purameter estimates (and standard enrors bncketed) for fiting equation (1) to $\log$ (soil SO) concentration for cach transect (NS = not significant)

\begin{tabular}{|c|c|c|c|c|}
\hline Transect & 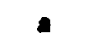 & $b$ & e & $d$ \\
\hline 1 & $\begin{array}{c}2.9 \\
(0.11) \\
2.30\end{array}$ & N S & N S & N S \\
\hline 2 & $\begin{array}{c}(0.39) \\
2.63\end{array}$ & $\begin{array}{c}0.0056 \\
(0.0010)\end{array}$ & $\begin{array}{l}-0.10 \\
(0.13)\end{array}$ & $\begin{array}{l}-\mathbf{0 . 0 0 0 7 8} \\
(0.00033)\end{array}$ \\
\hline 39 & $\begin{array}{l}(0.38) \\
2.85\end{array}$ & $\begin{array}{r}\mathbf{0 . 0 0 6 9} \\
(0.0010)\end{array}$ & $\begin{array}{l}-0.20 \\
(0.11)\end{array}$ & $\begin{array}{c}-0.00143 \\
(\mathbf{0 . 0 0 0 2 6 )}\end{array}$ \\
\hline $3 b$ & $(0.35)$ & $\begin{array}{c}-0.0006 \\
(0.0003)\end{array}$ & $\begin{array}{l}-0.24 \\
(0.09)\end{array}$ & N S \\
\hline 4 & $\begin{array}{c}3.10 \\
(0.48)\end{array}$ & $\begin{array}{r}0.0060 \\
(\mathbf{0 . 0 0 1 2})\end{array}$ & $\begin{array}{c}-0.26 \\
(0.13)\end{array}$ & $\begin{array}{c}-0.00069 \\
(0.00033)\end{array}$ \\
\hline 5 & $\begin{array}{c}2.62 \\
(0.27)\end{array}$ & $\begin{array}{c}0.0056 \\
(\mathbf{0 . 0 0 0 7 )}\end{array}$ & $\begin{array}{r}-0.09 \\
(0.06)\end{array}$ & $\begin{array}{r}-0.00106 \\
(0.00021)\end{array}$ \\
\hline
\end{tabular}

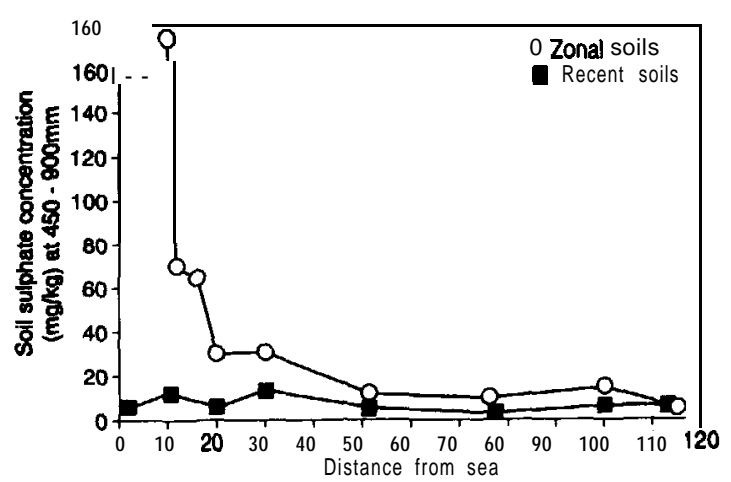

Figure 2 Relationship between mean soil sulphate concentrations $(450$ $900 \mathrm{~mm}$ depth) and distance from the cosst in zonal and recent soils (Transect 3).

erate reserves (347 ppm Mg 450-950 mm) about Blackmount on the Waiau River (Transect 1). from Fairfax to Wreys Bush (263-149 ppm Mg) on Transect 2, and from Gore north east to Tapsnui (133-242 ppm $\mathrm{Mg}$ ) on Transect 4. At the Lumsden site Mg reserves were about $3800 \mathrm{~kg}$ of exchangeable $\mathrm{Mg} / \mathrm{ha}$.

The association of high reserves with the river

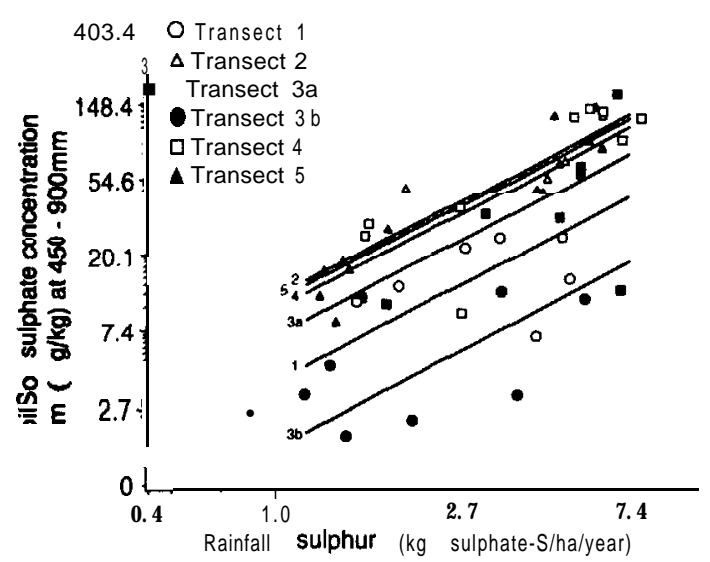

Figure 3 Relationship between annual sulphate $S$ input in rainfall end soil sulphate reserves $450-950 \mathrm{~mm}$ (log scales).

systems is in general agreement with the New Zealand Soil Bureau map of $\mathrm{Mg}$ reserves.

Available phosphorus was generally greatest in the surfacelayerofsoilanddeclined withdepthatmostsites (Figure 4). Phosphorus traditionally supplied in superphosphate $(9 \% \mathrm{P}, 11 \% \mathrm{~S})$ is largely retained in the topsoil, increasingly as organic-P as the land is developed, so variation between sites probably reflects different fertiliser histories.

High P levels below $450 \mathrm{~mm}$ were found only at inland sites at Kingston (81 ppm), Mossbum (34 pprn) and Waikoikoi (23 ppm); comparable levels (>60 ppm) have previously been recorded in the $0-100 \mathrm{~mm}$ depth in zonal soils in the upperreaches of the Mataura River (eg Athol to Kingston, Smith \& Risk unpublished). Future surveys may show more widespread reserves of subsoil $\mathrm{P}$ in dry inland situations.

Except for such areas sustainable agricultural systems in Southland will continue to require inputs of $\mathrm{P}$, since it is the key nutrient deficiency in Southland. Such inputs may be reduced by a practice such as subsoiling, where higher soil temperatures and improved aeration may lead tomore rapid recycling of organic material and may simultaneously increase reserves of organic matter at depth.

The reserves of potassium (K), organic carbon( $(O C)$, and total nitrogen $(\mathbf{N})$, were all concentrated in the surface layer of soil. There were geographical differences between transects; eg soils in the Waiau Valley (Transect 1) had more organic matter $(\mathrm{OC}, \mathrm{N})$ throughout the profile reserves than those on other transects $(\mathrm{P}$ $<0.05$ ); but lower (non significant) exchangeable-K reserves. Exchangeable- $K$ is not a good indicator of potassium reserves; a separate reserve- $K$ analysis provides a better measure. However single factor maps for reserve-K show Southland soils have low potassium 
reserves (NZ Soil Bureau 1962).

Thepattemofsodiumconcentrati onvari ed withsoil depth depending on distance from the coast Relatively high concentrations (11-28 ppm) were found in surface soils near the coast, and in the deeper part of the profile for inland soils, contrasting with concentrations below 5

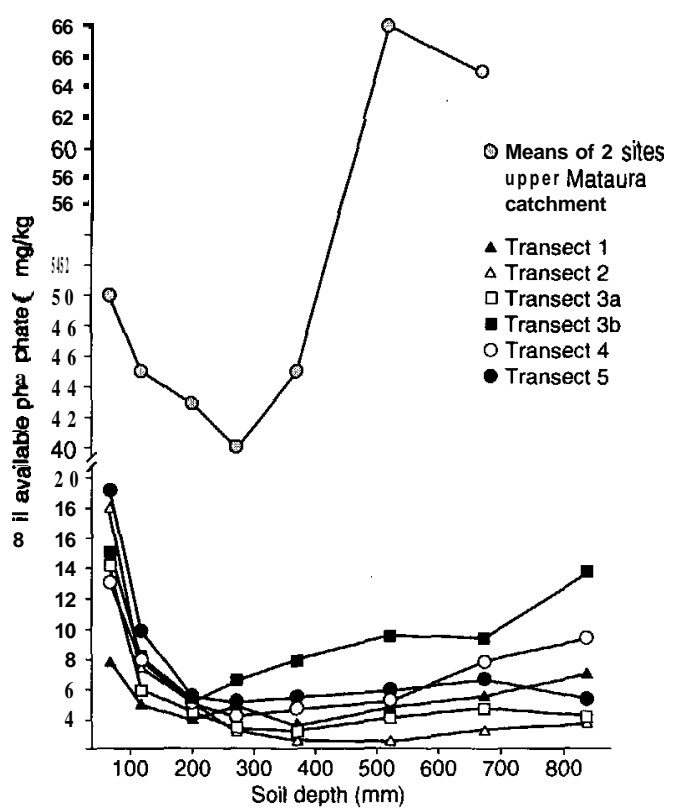

Figure 4 Mean available phosphate concentrations in the roil profiles for different transects and at two sites near Kingston.

ppm near the surface of inland soils.

There are areas of Southland soils from which reserves of sulphate could be exploited in the absence of $S$ fertilisers without limiting plant production, there are other (inland) areas where natural reserves of $\mathrm{Mg}$ should preclude the need for $\mathrm{Mg}$ fertiliser in the foreseeable future, and other small inland pockets of soil where $P$ reserves could be exploited while saving on $P$ fertiliser. In all cases the bulk of the reserves are deep in the profile relative to accepted 'normal' pasture rooting depths. Little is known of the possible movement of nutrients within the soil profile. Risk \& Boswell (1988) discussed the movement of sulphate upwards with the rising water table in Southland Plains soils in winter. The same mechanism could be expected to move $\mathrm{Mg}$ but probably not the $P$ because of both its low solubility and possibly lower water table in the inland P-rich soils.

An alternative strategy would be to encourage plant roots to grow deeper into the profile. With pastures this could involve the removal of physical barriers such as compacted soil layers (Greenwood \& McNamara 1992), or choice of species which are known to be deeper rooting than standard species. Cereals are generally deeper rooting than ryegrass and clovers, so cropping could be expected to increase the utilisation of the nutrient reserves. Deeper rooting trees could be expected to exploit the reserves even more, while a combination of tree crops at wide spacings and an understorey of pastoral or cereal or horticultural crops could represent the ultimate in sustainable systems. The trees would act as transport agents of nutrients stored at depth in the soil, returning them to the soil surface in leaf fall from which they would be incorporated into the topsoil and subsequently made available to the more shallow rooting crops. This is the key prerequisite for a sustainable agricultural system using the reserves of nutrients - there must be vertical recyding of the nutrients in the soil. If such systems were to be adopted it has to be recognised that the reserves reported occur in different locations, so that in one area the system might have adequate $S$ for example but still need regular input of other nutrients such as $\mathrm{P}$ and $\mathrm{K}$.

\section{REFERENCES}

Blakemore, L.C.; Searle, P.L.; Daly, B.K. 1977. Methods for chemical analysis of soils. New Zealand Soil Bureau Scientific Report 10A.

Boswell. C.C.; Risk, W.H.; Gray, G.M.; Swanney, B.; Smith, L.C. 1992. Sulphur in rainfall in Southland. Technical Report No 30 Invermay Agricultural Centre. New Zealand Pastoral Agriculture Research Institute Ltd.

Boswell, CC.; Risk, W.H.; Littlejohn, R.J. 1993. Atmospheric sulphur inputs in rainfall in southern New Zealand. Proceedings of the XVII International Grassland Congress (in press).

Greenwood, P.B.; McNamara, R.M. 1992. An analysis of the physical condition of two intensively grazed Southland soils. Proceedings New Zealand Grassland Association (in press).

N ew Zealand Soil Bureau (1962 and subsequently) Single factor maps. Department of Scientific and Industrial Research Wellington.

Risk. W.H.; Boswell,C.C. 1988. Sulphatesulphurin the subsoil of some Southland and Otago soils, pp 118-128. Towards the more efficient use of soil and fertiliser sulphur. White, R.E.; Currie, L.D. ed Massey University Palmerston N orth N ew Zealand.

Sindair, A.G.; Enright, P.D. 1982. An auto-analyser method for the determination of extractable soil sulphateusing automatedpurification of extracts. New Zealand Journal of Science 25: 14 1- 146. 